\title{
Komu wolno pójść na randkę? O seksualności osób z niepełnosprawnościami
}

\author{
Milena Trojanowska \\ Uniwersytet Łódzki, Szkoła Doktorska Nauk Społecznych
}

DOI: http://dx.doi.org/10.18778/1733-8069.16.3.04

Słowa kluczowe: niepełnosprawność, seksualność, związki, interakcjonizm symboliczny

\begin{abstract}
Abstrakt: Seksualność to nieoderwalna część naszej tożsamości. Poza grupą osób aseksualnych większa część społeczeństwa urodziła się i żyje jako istoty seksualne. Prawa biologii nie zawsze jednak wcielane są w konstruowane społecznie znaczenia. Czy kobiety z niepełnosprawnościami - w oczach społeczeństwa, partnerów i swoich - mają prawo pójść na randkę? Czy wolno im dbać o realizowanie potrzeb seksualnych? Jakie aktywności seksualne opisują społecznie akceptowane skrypty seksualne? Na te pytania spróbuję odpowiedzieć na podstawie analizy literatury oraz wyników badań własnych zrealizowanych w grupie kobiet żyjących z niepełnosprawnościami (stwardnienie rozsiane) i ich partnerów, a także na podstawie badań zrealizowanych w grupie osób niemających na co dzień kontaktu z osobami z niepełnosprawnościami.
\end{abstract}

Milena Trojanowska, socjolog, badaczka zajmująca się tematyką niepełnosprawności. Główne obszary zainteresowań to definiowanie niepełnosprawności, seksualność osób z niepełnosprawnościami, metodologia badań jakościowych. Doktorantka Szkoły Doktorskiej Nauk Społecznych, Uniwersytet Łódzki.

\author{
Adres kontaktowy: \\ Katedra Socjologii Organizacji i Zarządzania \\ Instytut Socjologii \\ Uniwersytet Łódzki \\ ul. Rewolucji 1905 r. nr 41/43, 90-214 Łódź \\ e-mail: trojanowska.milena@gmail.com
}




\section{Seksualność}

Seksualność towarzyszy człowiekowi od pierwszych dni życia. Możemy rozpatrywać ją na wielu płaszczyznach (Hawkes 2002). Biologicznie jesteśmy istotami seksualnymi, posiadającymi fizycznie manifestowaną płeć, zdolnymi do realizacji potrzeb seksualnych, a także do prokreacji. Seksualność wiąże się również z ludzką psychiką, poczuciem bycia istotną seksualną, zdolnością do oceny własnych potrzeb seksualnych. Na poziomie emocji seksualność przejawia się $\mathrm{w}$ reakcji na kontakt o podłożu seksualnym z samym sobą lub drugim człowiekiem. Wszystkie te przejawy seksualności zanurzone są w kontekście, w jakim funkcjonujemy. To, czy w dorosłym życiu nagość będzie wywoływała w nas wstyd, czy stanowiła naturalny element funkcjonowania, zależy od sposobu wychowania, przekazanej nam wiedzy, społecznych norm, sankcji, wzorów zachowań. Biologiczne i psychiczne uwarunkowania, w tym te dotyczące zachowań seksualnych, otoczone zostają społecznie konstruowanymi ramami. Ramy te nazywane są scenariuszami seksualnymi (sexual script) i stanowią drogowskaz, ,jakie uczucia i pragnienia mają charakter seksualny i jakie są właściwe scenariusze zachowań seksualnych. Skrypty seksualne mówią nam, gdzie, kiedy i z kim (w jakim wieku, jakiej rasy i z jakiej klasy) powinniśmy uprawiać seks oraz jakie jest jego znaczenie" (Seidman 2012: 70).

Gagnon i Simon (1973) idą dalej, mówiąc, że właściwie seksualność nie jest wrodzoną, biologicznie uwarunkowaną własnością każdego człowieka, a jest wynikiem etykietowania społecznego.

Deklaracja praw seksualnych, przyjęta i opublikowana przez Światową Organizację Zdrowia (World
Health Organization, skrót: WHO) w 2002 roku $^{1}$, traktuje seksualność jako „integralną część każdej istoty ludzkiej". Bardzo szerokie rozumienie tego pojęcia pozwala na zwrócenie uwagi na wiele aspektów życia, w których przejawia się seksualność: od potrzeb fizycznych, przez uczucia, emocje, a także wskazuje na otoczkę struktur społecznych, w której jest realizowana. Prawa seksualne w tej deklaracji nazwane są fundamentalnymi i uniwersalnymi prawami człowieka, a zapisane są w postaci jedenastu praw:

1. Prawo do wolności seksualnej.

2. Prawo do odrębności seksualnej, integralności oraz bezpieczeństwa seksualnego ciała.

3. Prawo do prywatności seksualnej.

4. Prawo do równości seksualnej.

5. Prawo do przyjemności seksualnej.

6. Prawo do emocjonalnego wyrażania seksualności.

7. Prawo do swobodnych kontaktów seksualnych.

8. Prawo do podejmowania wolnych i odpowiedzialnych decyzji dotyczących posiadania potomstwa.

9. Prawo do informacji seksualnej opartej na badaniach naukowych.

10. Prawo do wyczerpującej edukacji seksualnej.

11. Prawo do seksualnej opieki zdrowotnej (Deklaracja praw seksualnych 2003: 1-2).

Prawa te, chociaż ograniczane kontekstem społecznym, prawnym, kulturowym, historycznym, w większości przypadków są respektowane. W większości. Demokracja to ponoć rządy większości w trosce o dobro mniejszości. Czy tak dzieje się w przypadku mniejszości seksualnych? Czy doty-

${ }^{1}$ Powszechna deklaracja praw seksualnych, przyjęta i opublikowana przez Światową Organizację Zdrowia, jest dokumentem po raz pierwszy opublikowanym podczas XIV Światowego Kongresu Seksuologów w Hongkongu, 26 sierpnia 1999 roku. 
czy to również grup społecznych i jednostek, których zachowania seksualne nie wpisują się $\mathrm{w}$ ramy scenariuszy seksualnych? $\mathrm{Na}$ te pytania postaram się odpowiedzieć, analizując sytuację osób z niepełnosprawnościami, w szczególności kobiet z niepełnosprawnościami. Segregacja seksualna nie dotyczy bowiem tylko mniejszości seksualnych definiowanych przez przynależność do określonej tożsamości seksualnej. Dotyczy również grup, w których sposoby realizowania potrzeb seksualnych odbiegają od najczęściej pojawiających się społecznie scenariuszy. Osoby z różnymi niepełnosprawnościami muszą modyfikować dostępne scenariusze i adaptować je do własnych możliwości i potrzeb. Oznacza to zazwyczaj wyjście poza najczęściej realizowane scenariusze. Taka różnorodność nie jest niczym złym albo groźnym. Zagraża jednak pewnym schematom myślowym. Społecznie konstruowany świat, w którym różne zjawiska poddawane są ciągłym interpretacjom, zachowuje jednak pewien zrąb stałości. Znaczące odejście od tej konstrukcji może prowadzić do negatywnych sankcji wobec tych, którzy tego dokonują. Kochanowski pisze nawet o paranoi seksualnej, definiując ją w następujący sposób:

Paranoja antyseksualna to nie jest tylko przekonanie czy postawy poszczególnych jednostek wobec osób uprawiających seks niezgodny z kulturowymi skryptami normatywnych poprawności. To zinstytucjonalizowany, wbudowany w strukturę społeczną system dyskryminacji, upokarzania, marginalizowania, dyskredytowania, a także stosowania różnych form przemocy (w tym fizycznej) wobec osób seksualnie niesubordynowanych. (2013: 19)

Zarówno na poziomie interakcji jednostek, jak i społeczeństwa może dochodzić do tego rodzaju zjawisk. Czasami ich przyczyną jest błąd chybionej skali, jak nazywała to Gayle Rubin (2004), czyli budowanie tożsamości społecznej jednostki na podstawie cech, które z punktu widzenia zarówno jednostki, jak i społeczeństwa nie są najbardziej istotne. Weźmy przykład polityka jeżdżącego na wózku. Z punktu widzenia społecznego istotnymi cechami tej jednostki powinny być między innymi inteligencja, empatia czy sprawczość. Postrzeganie tego mężczyzny tylko przez pryzmat niepełnosprawności będzie błędem chybionej skali, bowiem poruszanie się na wózku nie wpływa na jego zdolność oceny przydatności danej ustawy dla społeczeństwa.

Wracając do tematu seksualności, Sigmund Freud (1999) opisał dwa ekstrema związane z seksualnością. Pierwsze to sytuacja nadmiernej kontroli społecznej, która prowadzi do zaniechania przez jednostkę realizacji potrzeb seksualnych i może być przyczyną zaburzeń. Drugie ekstremum to całkowita swoboda seksualna, której negatywnym efektem może być pojawienie się perwersji oraz brak stabilności. W przypadku osób z niepełnosprawnością zdaje się, że mamy do czynienia z tym pierwszym. Wśród norm nie ma zbyt wielu takich, w które mogłyby się wpisać osoby z niepełnosprawnościami i ich sposoby realizowania potrzeb seksualnych.

Steven Seidman (2012: 75), interpretując słowa Michela Foucaulta, stwierdza, że: „nie rodzimy się jako istoty seksualne, lecz raczej uczymy się nimi być, i dzieje się tak jedynie w tym społeczeństwach, które wynalazły ideę «seksualności»".

Więc już nie tylko normy ograniczają realizację potrzeb seksualnych, ale sama seksualność jest konstruktem społecznym. Tym samym zakwestionowane zostało pierwszeństwo biologicznego warunku seksualności. Sytuacja wielu osób z niepełnosprawnościami przeczy tej teorii. Odseparowani 
od tematu seksualności, pozbawieni edukacji i wiedzy w tym zakresie często przejawiają potrzeby seksualne i realizują je.

Jak postaram się wykazać w dalszej części tekstu, w kwestii seksualności element biologiczny i społeczny są ze sobą nierozerwalnie połączone. Przede wszystkim jednak postaram się odpowiedzieć na pytanie o warunki realizowania potrzeb seksualnych przez osoby z niepełnosprawnościami oraz społeczne postrzeganie seksualności osób z niepełnosprawnościami. Komu wolno pójść na randkę, a komu w społecznym przekonaniu nie i dlaczego?

\section{Metodologia badań}

Jak pisał Jacek Kochanowski w Socjologii seksualności (2013), tylko odwołanie się do konkretnego doświadczenia, konkretnego ciała, pozwala nam na zrozumienie, czym jest ciało jako twór nie tylko biologiczny, ale również społeczny. Przecież każde ciało osadzone jest w konkretnym kontekście. Oczywiście, można zauważyć pewne schematy powtarzające się $\mathrm{w}$ przypadku wielu ciał i towarzyszących im kontekstów. Jednak tylko pokazanie konkretnych przykładów, konkretnych ciał pozwala nam urealnić tezy i hipotezy. Te konkretne ciała są, jak można powiedzieć za Pierrem Bourdieu (2005), medium społecznej dystynkcji. Co to oznacza dla naszym rozważań nad sposobem realizowania swoich potrzeb seksualnych przez osoby z niepełnosprawnością? Tyle, że dystynkcje niepełnosprawnych ciał pozwalają na coś, co Foucault (1998) nazywał jednym z rodzajów obiektywizacji zjawiska - praktyki dzielące. Doświadczenia wielu ciał pozwalają na dostrzeżenie tego podziału: sprawny-niesprawny. Odbywa się on oczywiście na różnych poziomach. Nie zawsze organoleptycznie jesteśmy w stanie ocenić, czy w przypadku danego ciała zjawisko niepełnosprawności występuje, czy nie. Czasami służą do tego instrumenty prawne $\mathrm{w}$ postaci komisji orzekających o istnieniu niepełnosprawności i jej stopniu. Czasami podział ten następuje na poziomie społecznym, kiedy dane dziecko kierowane jest do szkoły specjalnej, co w kontekście tożsamości społecznej gwarantuje jego przynależność do grupy osób z niepełnosprawnością. Jak zobiektywizowanie się tego zjawiska wpływa na doświadczenie randkowania niepełnosprawnego ciała? Jaki rodzaj obiektywizacji poprzez praktyki dzielące ma największy wpływ na sposób realizowania swoich potrzeb seksualnych? Na to pytanie postaram się odpowiedzieć, odwołując się właśnie między innymi do doświadczeń konkretnych ciał.

W tym tekście przedstawione zostały wyniki analizy danych pozyskanych przy użyciu kilku metod. Pierwsza z nich to desk research dokonany w okresie od grudnia 2018 r. do marca 2019 r. Wyszukiwane słowa: disability, sexuality (współwystępowanie słów), platforma Ebsco, czasopisma naukowe recenzowane (rok wydania: nie starsze niż 2000). Druga metoda to zogniskowane wywiady fokusowe przeprowadzone w okresie od czerwca do sierpnia 2019 r. w Warszawie. Przeprowadzono 4 wywiady zogniskowane z grupami: dwie grupy otwarte osób, które nie mają na co dzień kontaktu z osobami zdiagnozowanymi na rzutowo-remisyjną postać stwardnienia rozsianego (skrót: RRMS); kobiety ze zdiagnozowanym RRMS; partnerzy kobiet ze zdiagnozowanym RRMS. Grupy liczyły od 4 do 5 osób. Badanie było badaniem kontekstowym stanowiącym pierwszy element badania nad tożsamością płciową kobiet żyjących z niepełnosprawnościami. Podstawowe pytania badawcze to: w jaki sposób społecznie postrzegana jest tożsamość płciowa ko- 
biet żyjących z niepełnosprawnościami w trzech wymiarach: związki, macierzyństwo, seksualność? Badanie zostało przeprowadzane w oparciu o teorię interakcjonizmu symbolicznego, teorię ugruntowaną i założenia socjologii seksualności (Konecki 2000; Seidman 2012; Kochanowski 2013; Glaser, Strauss 2016). Przy wyborze badanej grupy, czyli kobiet żyjących ze stwardnieniem rozsianym, kierowałam się specyfiką choroby. Ze względu na swój przewlekły i nielinearny przebieg stanowi ona zagrożenie dla poczucia tożsamości jednostki. Wymusza nieustanne dostosowywanie się i zmiany. Choroba najczęściej przebiega w formie rzutowo-remisyjnej (Polskie Towarzystwo Stwardnienia Rozsianego 2006), co oznacza, że po okresie pogorszenia stanu zdrowia następuje powrót do całkowitej lub prawie całkowitej sprawności. Osoby te wielokrotnie doświadczają reinterpretacji swojej tożsamości wraz z przebiegiem choroby na continuum osoba sprawna-osoba niepełnosprawna. Ich unikatowe doświadczenie stanowić będzie podstawę do zbadania, w jaki sposób jednostka interpretuje i internalizuje społeczne normy, realizuje je w otaczającym ją świecie.

Ostatnia wykorzystywana przy pracy nad zaprezentowanym materiałem metoda badawcza to autoetnografia. Autorka od kilkunastu lat jest osobą żyjącą z niepełnosprawnością i aktywnie uczestniczy w działaniach formalnych i nieformalnych grup działających na rzecz tego środowiska. W trakcie tych aktywności prowadzi obserwacje uczestniczące. Analiza tematu seksualności osób z niepełnosprawnościami opiera się głównie o dane zastane i wyniki badań własnych. Element autoetnograficzny stanowi dodatkowe źródło wiedzy, nie podstawowe. $\mathrm{W}$ niniejszej pracy będzie przedstawiony w formie komentarzy, pytań, sugestii interpretacyjnych.

\section{Polska i światowa literatura na temat seksualność osób z niepełnosprawnościami}

W tej części tekstu chciałabym przeanalizować dostępną literaturę naukową pod kątem wiedzy na temat seksualności osób z niepełnosprawnościami. Ten przegląd stanowić będzie wstęp do dalszych rozważań opartych o wyniki badań własnych.

Jak zostało wspomniane wcześniej, seksualność osób z niepełnosprawnościami wykracza poza skrypty seksualne obecne $\mathrm{w}$ wielu kulturach i społecznościach. Celowo zaznaczam, że nie jest tutaj mowa tylko o kulturze polskiej i innych europejskich kulturach, bowiem w przeglądzie literatury znalazły się również pozycje odnoszące się do azjatyckich i afrykańskich społeczeństw. Okazuje się, co postaram się przedstawić za chwilę, że te skrypty nie są znacząco odmienne na różnych kontynentach.

Jak pisze Seidman (2012: 57): ,jednym z największych osiągnięć Karola Marksa było stwierdzenie, że natura ludzka jest kształtowana przez społeczeństwo i podlega zmianom historycznym". W kontekście posiadanej wiedzy nie sposób zarzucić temu stwierdzeniu nieprawdziwości. Świadczyć może o tym chociażby pojawianie się w różnych okresach różnych modeli niepełnosprawności (Wiliński 2010; Rzeźnicka-Krupa 2019). Model medyczny, odpowiadający okresowi rozwoju medycyny, leczenia farmakologicznego. Model społeczny, zwracający uwagę na konieczność dostosowania rozwijającego się świata i przestrzeni publicznej do potrzeb osób z różnymi niepełnosprawnościami. Model feministyczny, kulturowy, bioróżnorodności i inne. Do tych modeli będę się również odwoływała w dalszej części tekstu. 
W literaturze nie brakuje głosów i dowodów na to, że model medyczny niepełnosprawności nie został wyparty przez kolejno pojawiające się inne modele. W kontekście dostępu do opieki medycznej dla kobiet w ciąży oraz opieki ginekologicznej wciąż narzucana jest kobietom narracja myślenia o swoim ciele jako ciele niezdolnym do realizowania potrzeb seksualnych i niezdolnym do rodzicielstwa, opieki nad potomstwem. Ciele ograniczonym i wymagającym medycznej troski. Kobiety nie są postrzegane jako ekspertki w kwestii własnego ciała, a prawo do podejmowania decyzji jest im odbierane, o czym pisze między innymi Lesley Tarasoff (2015). Na polskim gruncie taką tezę potwierdza raport „Przychodzi baba do lekarza" wydany przez Fundacje Kulawa Warszawa (2019). Interpretacja niepełnosprawności narzucana jest tym kobietom, a wraz z określoną interpretacją niepełnosprawności narzucane są scenariusze seksualne. Personelowi medycznemu brakuje świadomości tego, jak faktycznie wygląda doświadczenie niepełnosprawności. Wciąż istnieje problem z respektowaniem założeń holistycznego podejścia do niepełnosprawności na rzecz podejścia medycznego, które lokuje przyczyny i konsekwencje niepełnosprawności w jednostce, dając sobie jednocześnie przywilej władzy realizowany poprzez kierowanie działaniami niepełnosprawnej jednostki. Władzę rozumiem tutaj za Foucaultem właśnie jako działanie na działanie (1998). Czasami władza ta okazywana jest wprost, przejawia się w rozkazach i zakazach dotyczących zachowań niepełnosprawnego ciała. Tarasoff (2015) pisze również o gorszym dostępie do edukacji, w tym edukacji seksualnej, niskim odsetku kobiet z niepełnosprawnością żyjących w związkach małżeńskich, doświadczających rozwodów i separacji, a także doświadczaniu przemocy seksualnej, w tym ze strony opiekunów. Nie dokonuje jednak próby wyjaśnienia przyczyn tej sytuacji.
Feministyczne studia o niepełnosprawności przywróciły kobietom ich ciała, płeć, potrzeby seksualne. Społeczny model niepełnosprawności skupiał się bowiem na męskiej płci. Feministyczne studia oddały głos kobiecym ciałom, a tym samym uwidoczniły kolejny problem - podwójną dyskryminację (Santos, Santos 2018). Do tego wątku powrócę jeszcze przy analizie wyników badań własnych, chciałabym tutaj jednak zaznaczyć, że taka kwestia pojawiła się $\mathrm{w}$ dyskursie naukowym. Feministyczne podejście ujawniło brak wiedzy na temat doświadczeń kobiecego ciała w kontekście niepełnosprawności. Trudno zaprzeczyć zdaniu, że płeć warunkuje doświadczenie. Przyczynia się do tego zarówno biologia, jak i społeczna wiedza, kultura czy religia. Susan Wendell (1989: 104) poszła nawet dalej w swojej argumentacji, mówiąc, że: „potrzebujemy feministycznej teorii niepełnosprawności, ponieważ opresja nakładana na osoby niepełnosprawne jest bliska kulturowej opresji ciała. Niepełnosprawność nie jest biologicznie uwarunkowana, tak jak płeć jest społecznym konstruktem opartym o biologiczne podstawy" (tłum. własne).

Nie zgadzam się z poglądem, że płeć i niepełnosprawność są tworami wyłącznie społecznymi, bliższa jest mi teoria bioróżnorodności w kontekście niepełnosprawności, niemniej $\mathrm{w}$ pełni zgadzam się ze stwierdzeniem, że istnieje i jest doświadczana przez kobiety z niepełnosprawnością podwójna dyskryminacja i ma to związek z płcią. Santos i Santos piszą też o innych podnoszonych przez feministyczne ruchy kwestiach związanych z seksualnością kobiet z niepełnosprawnościami. Postrzeganie niepełnosprawnych ciał jako aseksualnych. Postrzeganie seksualności przez pryzmat stosunku genitalnego i uznawanie takiego scenariusza za jedyny dopuszczalny. Strach wywołany brakiem wiedzy na temat seksualności 
osób z niepełnosprawnościami. Brak prywatności i przestrzeni do realizowania potrzeb seksualnych w przypadku osób długo hospitalizowanych i przebywających długookresowo w placówkach medycznych i opiekuńczych. Doświadczenie kontroli ze strony opiekunów, rodziców, personelu medycznego, co prowadzi do zaniku życia towarzyskiego i seksualnego osoby z niepełnosprawnością lub niepojawienia się go w przypadku dzieci i nastolatków. Wskazówką jest zdanie mówiące o aseksualności jako konsekwencji deseksualizacji osób z niepełnosprawnościami. Część osób z niepełnosprawnościami z różnych przyczyn nie może odbyć stosunku genitalnego. Ten najczęściej realizowany i uznawany za normę scenariusz seksualny nie jest dla nich dostępny, dlatego niesłusznie etykietuje się osoby $\mathrm{z}$ niepełnosprawnościami jako aseksualne. Tymczasem, jak pisze Siebers (2012), ludzka seksualność jest elastyczna. Strefy erogenne nie znajdują się tylko w genitaliach, a stosunek genitalny nie jest jedynym scenariuszem, który może przynosić satysfakcję seksualną. Dalej w tych rozważaniach idzie Tom Shakespeare (1996: 106 za: Santos, Santos 2018), który wysuwa z tego stwierdzenia następujący wniosek: „ponieważ osoby niepełnosprawne nie są w stanie uprawiać miłości w bezpośredni sposób lub w konwencjonalnych pozycjach, są zmuszone eksperymentować i w konsekwencji cieszą się bardziej interesującym życiem erotycznym". Ma to dowodzić zewnętrznej przyczyny nierealizowania swoich potrzeb seksualnych przez osoby z niepełnosprawnościami. Ograniczenie dostępności różnorodnych skryptów seksualnych przyczynia się do przekonania, że tylko seks genitalny może przynosić satysfakcję. Brak możliwości jego realizacji równoznaczny jest $\mathrm{z}$ nierealizowaniem potrzeb seksualnych. Przeczy temu sama biologia, która wyposażyła człowiek w płynną i elastyczną seksualność. Jednak inne niż genitalne sposoby realizowania seksualności nie mają celu prokreacyjnego, który to cel często jest w społeczeństwach uważany za jeden z podstawowych w kontekście seksu. Jak pisze Tepper (2000), osoby z niepełnosprawnością nie są postrzegane jako potencjalni rodzice, więc po co temat seksualności miałby ich interesować? Są społecznie postrzegane jako jednostki wymagające opieki. Taki trop narracyjny potwierdzają również moje badania.

Jest jednak pewien wątek, który jest w stanie połączyć narrację medyczną niepełnosprawności i seksualność. The pleasure of sex to zjawisko opisane przez Sarah Smith Rainey (2018). Realizacja potrzeb seksualnych widziana jest tutaj jako element działań opiekuńczych i na odwrót - działania opiekuńcze mogą stać się sposobem realizowania potrzeb seksualnych lub być grą wstępną. Smith Rainey wplotła wątek prywatnych doświadczeń w swoje badania nad seksualnością osób z niepełnosprawnościami. Ten autoetnograficzny wątek jej pracy jest egzemplifikacją tezy o społecznym charakterze barier $\mathrm{w}$ realizacji potrzeb seksualnych osób z niepełnosprawnościami. Jej chorujący na stwardnienie rozsiane chłopak był osobą niezdolną do realizowania potrzeb seksualnych według uznawanych za normalne skryptów seksualnych.

Postrzeganie osób z niepełnosprawnościami jako niezdolnych do prowadzenia aktywnego i satysfakcjonującego życia seksualnego nie ma granic kulturowych i etnicznych. Prowadzone w Wietnamie badania ujawnily te same stereotypy na temat osób z niepełnosprawnością ruchową: są postrzegane jako nieatrakcyjne, aseksualne i niezdolne do aktywności seksualnej (Nguyen 2019), podobnie jak w przypadku badań prowadzonych w południowej Afryce (Hunt 2017). Próby podej- 
mowania aktywności seksualnej często prowadzą do odmiennego etykietowania - jako osoby hiperseksualnej, perwersyjnej. Seksualność osób z niepełnosprawnością nie mieści się w żadnej normie społecznej, a wyjście poza tę normę jest negatywnie sankcjonowane. Co ciekawe, barierami w pójściu na randkę $\mathrm{z}$ osobą $\mathrm{z}$ niepełnosprawnością ruchową są bariery społeczne: stygmatyzacja społeczna (obawa o transferowanie stygmatyzacji na partnera), obawa o konieczność sprawowania stałej opieki nad partnerem lub partnerką z niepełnosprawnością (Hunt 2017). Po raz kolejny w narracji o seksualności osób z niepełnosprawnościami pojawia się wątek niezależności, który wydaje się być bardzo istotny w tym kontekście.

O innych wątkach pisze Tom Shakespeare. $\mathrm{W}$ jego przekonaniu „problemem seksualności niepełnosprawnych nie jest to, jak to zrobić, ale $\mathrm{z}$ kim to robić" (Shakespeare 2000: 161 [tłum. własne]). Seksualność osób z niepełnosprawnościami ma bowiem dużo więcej wymiarów, niż zostało to do tej pory wspomniane. Shakespeare wymienia między innymi kwestie ekonomiczne - niektórych nie stać na ubrania, na środki czystości, wyjście na miasto, życie towarzyskie, a przecież potencjalnego partnera seksualnego trzeba gdzieś poznać. Brak styczności przestrzennej to uniemożliwia. Stąd nierzadko w szpitalach lub innych placówkach opieki zdrowotnej dochodzi do aktów seksualnych lub nawiązywania innych relacji intymnych.

Za Zygmuntem Baumanem Shakespeare powtarza też, że współczesna obsesja na punkcie seksu i jego wszechobecność w przestrzeni publicznej nie sprzyjają likwidacji barier w realizowaniu potrzeb seksualnych. Wyobrażenia podsycane przez konsumpcyjną wizję seksu nie mogą być zrealizowane przez wszystkich bądź ich realizacja może nie przynieść oczekiwanego poziomu satysfakcji.

\section{Badanie własne - komu w Polsce wolno pójść na randkę i dlaczego?}

Jak zostało powiedziane wcześniej, seksualność osób z niepełnosprawnością ma wiele wymiarów: fizyczny, społeczny, ekonomiczny, emocjonalny, psychiczny, polityczny, kulturowy. Jak piszą Jakub Niedbalski, Mariola Racław i Dorota Żuchowska-Skiba (2017), wśród polskich socjologów coraz częściej dostrzegane są te perspektywy, a co za tym idzie, dostrzegane są różne przyczyny i konsekwencje niepełnosprawności. Niektórzy badacze w swoich pracach postulują o uznanie niepełnosprawności jako „funkcji stosunku pomiędzy osobami niepełnosprawnymi a ich otoczeniem" (Kossakowski 2003 za: Hinc-Wirkus 2017: 28-29). Oznaczałoby to, że niepełnosprawność jest konstruktem społecznym. W teorii można zatem wyobrazić sobie taką sytuację, że przy ustąpieniu wszystkich barier wynikających z wzajemnych stosunków niepełnosprawność by nie istniała. Czy faktycznie tak jest? Moim zdaniem zwrot $\mathrm{w}$ badaniach o niepełnosprawności ku założeniom bioróżnorodności, odwołując się do biologii człowieka, jest tego zaprzeczeniem.

Pokrótce zostało opisane, w jaki sposób niepełnosprawność obiektywizuje się w naukach społecznych. A w jaki sposób obiektywizuje się w społeczeństwie? W jaki sposób o tym zjawisku mówią, jak je interpretują uczestnicy życia codziennego - ci, którzy stykają się z nim na co dzień lub nie? Ciekawi mnie również kwestia przekładalności tych codziennych interpretacji w interakcjach na wiedzę naukową. Te zagadnienia ciekawiły mnie szczególnie podczas realizowania badań i analizy zebranego materiału.

Zanim przejdę do analizy treści związanych z seksualnością osób z niepełnosprawnościami, na po- 
czątku chciałabym pokrótce opisać kilka bardziej ogólnych wniosków z badania, związanych z samym interpretowaniem niepełnosprawności. Po pierwsze, zarówno osoby niemające na co dzień styczności z niepełnosprawnością, jak i te, które mają taką styczność lub same doświadczają niepełnosprawności, dokonują rozróżnienia dwóch rodzajów niepełnosprawności: intelektualnej i innych, związanych z utratą sprawności fizycznej lub utratą któregoś ze zmysłów. Niepełnosprawność ruchowa lub niesprawność zmysłów postrzegane są jako te, które mogą nie zagrażać komunikacji między jednostkami i które mogą być kompensowane przez technologie, przystosowanie przestrzeni publicznej. Niepełnosprawność intelektualna, jak powiedziała jedna z badanych, może wywoływać strach, obawę. Niepełnosprawność intelektualna, zdaniem badanych, wpływa na zdolność jednostek do nawiązywania relacji, $\mathrm{w}$ tym relacji seksualnych.

O ile osoby niepełnosprawne, ale z niepełnosprawnością fizyczną, jednak odbieramy jako takie, które mają świadomość i zdolność decydowania o sobie, to osoby z upośledzeniem intelektualnym są już odbierane jako nie do końca świadome tego, co się dzieje i mogą być wykorzystane przez to. (kobieta, brak kontaktu z osobami z niepełnosprawnością)

Związek to przecież nie tylko relacje seksualne, ale również nieustanna komunikacja swojego stanu, sposobu widzenia świata, potrzeb, oczekiwań, a także przekazywanie informacji, uzyskiwanie ich od drugiej osoby. Osoby z niepełnosprawnością intelektualną postrzegane są jako te, w relacji z którymi przepływ informacji może być zaburzony lub w ogóle niemożliwy.

Duże znaczenie ma stopień niepełnosprawności intelektualnej wpływający na stopień możliwości formułowania komunikatów i posługiwania się symbolami. Zdaniem badanych niepełnosprawność intelektualna wpływa również na zdolność do rozpoznania kontekstu sytuacji i odpowiedniego zinterpretowania go. Brak ten może być przyczyną wykorzystania osoby z niepełnosprawnością intelektualną przez inną osobę, która będzie zdolna narzucić interpretację znaczeń obecnych w danej sytuacji i interpretację kontekstu. Aspekt komunikacji wydaje się być bardzo istotnym w kontekście seksualności. Brak umiejętności odpowiedniego interpretowania symboli powszechnie pojawiających się w społeczeństwie może doprowadzić do złej ich interpretacji. Takie obawy wyrażali badani, mówiąc, że baliby się spotykać $\mathrm{w}$ celach intymnych $\mathrm{z}$ osobą z niepełnosprawnością intelektualną $\mathrm{w}$ obawie o brak możliwości swobodnego komunikowania się z daną osobą oraz strach przed błędnym zinterpretowaniem ich działania przez osoby z zewnątrz. Postrzeganie osób z niepełnosprawnością intelektualną jako niezdolnych do poprawnego formułowania i odczytywania komunikatów prowadzi do niepewności w interpretacji celów, w jakich inni nawiązują z nim relacje seksualne.

Bo jak może osoba normalna dogadać się z niepełnosprawną umysłowo? Nić porozumienia musi być. (mężczyzna, brak kontaktu z osobami z niepełnosprawnością)

Ta wiedza prowadzi do pewnego tropu interpretacyjnego. Osoby z niepełnosprawnością na całym świecie bywają postrzegane jako aseksualne, czasami osoby z niepełnosprawnością intelektualną traktuje się jak dzieci, czego przejawem jest zdrabnianie ich imion, mówienie do nich po imieniu, dotykanie ich ciała bez uzyskania pozwolenia. Działania te przypominają działania podejmowane przez dorosłych wobec dzieci, które również, z innych po- 
wodów niż osoby z niepełnosprawnością intelektualną, nie są zdolne do przekładania swoich myśli i potrzeb na komunikaty werbalne i niewerbalne zrozumiałe dla innych jednostek.

Teoretycznie mężczyzna na początku zwróci uwagę u kobiety [z niepełnosprawnością intelektualną] na wygląd, ale jeżeli szuka związku, to dla niego ważne jest, żeby z tą osobą się komunikować i dzielić życie. (kobieta, brak kontaktu z osobami z niepełnosprawnością)

Inny trop narracyjny podjęły kobiety z niepełnosprawnościami, wskazując, że czasami to związek dwóch osób z niepełnosprawnością może być typem relacji, gdzie dochodzi do zaistnienia wspólnego zasobu wiedzy, symboli.

Dwie osoby niepełnosprawne lepiej sobie radzą i lepiej się rozumieją, niż jak jest jedna niepełnosprawna, bo ta druga osoba sprawna nie zawsze jest w pełni świadoma. (kobietami z niepełnosprawnością [SM])

Ta wypowiedź pokazuje też, że w przypadku osób z niepełnosprawnością nie możemy mówić o „braku”, ale o „inności”. Ta inność musi też zostać poprawnie zinterpretowana, w sposób neutralny, nie wartościujący. Taka narracja bliska jest narracji o niepełnosprawności jako formie bioróżnorodności.

Kolejnym istotnym wątkiem, który wyraźnie wybrzmiał w badaniu, była fizyczność. Kobiety z niepełnosprawnością dbające o swój wygląd zewnętrzny wywołują dysonans poznawczy. Zakotwiczona $w$ interpretacji społecznej egzemplifikacja kobiety z niepełnosprawnością zawiera raczej elementy medyczne (wózek), wywołuje określone emocje (litość). W sprzeczności w tymi desygnatami i emocjami stoi zadbany wygląd fizyczny, który jednocześnie ma duże znaczenie $\mathrm{w}$ procesie interpretacji niepełnosprawności w przypadku konkretnej interakcji.

Ja myślę, że to zależy tylko i wyłącznie od wyglądu tej pani (...), czy jest atrakcyjna, czy nie. (partner kobiety z niepełnosprawnością $[\mathrm{SM}])$

Atrakcyjny wygląd fizyczny stanowi przepustkę do zdefiniowania kobiety jako atrakcyjnej potencjalnej partnerki. Z fizycznego punktu widzenia kobieta, która nie ma nogi lub ręki, porusza się na wózku, może kompensować swoje bariery dzięki technologii (korzystając na przykład z protezy). Podobnie jest $\mathrm{w}$ przypadku osób z niepełnosprawnością wzroku lub słuchu. Możliwość kompensacji barier wynikających z niepełnosprawności zdaje się być istotnym czynnikiem wpływającym na postrzeganie danej jednostki z niepełnosprawnością jako atrakcyjnej jako potencjalny partner seksualny lub życiowy. Duże znaczenie ma tutaj oczywiście dostosowanie przestrzeni publicznej do możliwości takich osób. Wygląd fizyczny jest jednak w przypadku pierwszego kontaktu jedynym z niewielu źródeł informacji, jaki posiadamy bez angażowania wysiłku i czasu w zdobycie go. Dlatego on znacząco wpływa na kierunek interpretacji niepełnosprawności $\mathrm{w}$ interakcji. Jak wynika z przeprowadzonego badania, w przypadku mężczyzn i możliwości zdefiniowania kobiety jako atrakcyjnej potencjalnej partnerki znaczenie ma również zdolność kobiety do posiadania potomstwa. Niepełnosprawność, która może wskazywać na jej nabyty charakter, niezwiązany z pulą genów, jest odbierana jako potencjalnie mniej zagrażająca zdrowiu przyszłego potomstwa. Interpretacja ta prowadzi nas do biologicznego modelu niepełnosprawności, który analizuje niepełnosprawność jako zjawisko jednostkowe i umiejscowione w ciele. 
Zdolność kobiety do zadbania o swój wygląd przekłada się również na zdolność do samodzielnego funkcjonowania. Zdolność do wykonywania czynności higienicznych sugeruje większą niezależność jednostki. Jak wcześniej zostało wspomniane, między innymi Xanthe Hunt (2017) pisała o niezależności jako czynniku sprzyjającym realizowaniu potrzeb seksualnych przez osoby z niepełnosprawnością. Szczególnie mężczyźni będący w związku z niepełnosprawnymi kobietami zauważali fakt obawy środowiska, bliskiego i dalszego, o tożsamość społeczną mężczyzny w takim związku.

Można było spotkać się ze stwierdzeniem, że jestem bardziej opiekunem niż mężem, facetem. To bardziej osoby, które nas nie znały. (mąż kobiety z niepełnosprawnością [SM])

Zdolność do niezależności zdaje się być istotnym faktem wpływającym na postrzeganie kobiety z niepełnosprawnością jako atrakcyjnej partnerki życiowej i seksualnej. Niezależność partnerki gwarantuje pozostanie w roli partnera, a nie opiekuna. Sarah Smith Rainey (2018) pisała wprost, że łączenie tych ról nie jest możliwe w przypadku każdego związku, a czerpanie przyjemności seksualnej z wykonywania czynności higienicznych, rehabilitacyjnych, wymaga odpowiedniego podejścia obu stron. Nie każdy tego chce.

Wejście w związek z partnerem zależnym może spowodować zmiany w życiu, w tym w obszarach pracy, życia rodzinnego, towarzyskiego, co rodzi pewne obawy.

Powiem, że on jest bardzo tolerancyjny, ale właśnie przez długi czas musiałam go przekonywać, że spotykając się ze mną, nic mu nie grozi i że ja robię wszystko samodzielnie, że dbam o siebie, bo chcę zachować jak najdłużej zdrowie. (kobieta z niepełnosprawnością [SM])
Na możliwość niezależnego życia w przypadku osób z niepełnosprawnościami wpływają wszystkie powyżej opisane czynniki: komunikacja, kompensacja niepełnosprawności i warunki fizyczne. Nawiązując do wcześniej przedstawionego przeglądu literatury na temat seksualności osób z niepełnosprawnościami, tego rodzaju czynniki mogą tłumaczyć występowanie podobnych lub takich samych stereotypów dotyczących osób z niepełnosprawnościami na całym świecie. Wśród tych trzech czynników to kompensacja jest tym, na który największy wpływ mają czynniki ekonomiczne, społeczne, polityczne, technologiczne, czyli leżące poza jednostką, a których istnienie silnie zaznacza społeczny model niepełnosprawności. Chciałabym tylko w tym miejscu zaznaczyć, że zarówno intuicją badanych, jak i moim spostrzeżeniem po wieloletniej pracy w środowisku osób z niepełnosprawnościami jest to, że kluczowym czynnikiem pozwalającym na zbudowanie świata pozwalającego na kompensację biologicznych ograniczeń jest styczność przestrzenna i doświadczenie relacji. Hipotezę tę potwierdzają badani.

Myślę, że każdy, kto jak był mały, miał do czynienia lub widział jakieś niepełnosprawności, to jest mimo wszystko inaczej. A jeżeli jest osoba, która nie miała kogoś takiego w swoim otoczeniu, to nie rozumie. (kobieta z niepełnosprawnością [SM])

Brak doświadczenia kontaktu z osobami z niepełnosprawnością wywołuje strach i niepewność w kontakcie bezpośrednim. Jednocześnie brak styczności ze zjawiskiem niepełnosprawności wywołuje w osobach $\mathrm{z}$ nabytą niepełnosprawnością lęk w momencie jej nabycia. To sprzyja zanikowi kontaktów towarzyskich i utrudnia realizacje potrzeb seksualnych $\mathrm{w}$ relacji z innymi jednostkami. 


\section{Podsumowanie}

Marks miał rację, twierdząc, że natura ludzka podlega zmianom inspirowanym społecznie i historycznie (Walentynowicz 2018). To stwierdzenie prowadzi mnie do pytania: czy jest coś, co zmianom nie podlega? Biologia. Oczywiście, świat natury podlega różnym modyfikacjom i przemianom spowodowanym przez działania człowieka i bieg czasu. Jednak w świecie pozostaje jednym z najbardziej trwałych i niezmiennych elementów. Pewnym tropem wynikającym z analizy materiału z badań własnych jest to, że obiektywizacja przez podział w przypadku osób z niepełnosprawnościami w kontekście seksualności realizuje się głównie na poziomie właśnie biologicznym. W wypowiedziach badanych inne sposoby obiektywizacji (prawne, instytucjonalne) nie zostały nawet wspomniane. Nie oznacza to, że nie istnieją w ogóle, ale nie pojawiały się jako istotny element w świadomości osób badanych. Biologia jest kwestią niezaprzeczalnie istotną i dostrzeganą przez ludzi.

Niemniej jestem przekonana, że większość barier w realizacji potrzeb seksualnych jest barierami wtórnymi. Nie ma pierwotnej bariery w realizacji potrzeb seksualnych. Ludzka seksualność jest elastyczna i płynna i to również wynika z naszej biologii. Może to zaprzeczać obecnym w naszym społeczeństwie skryptom seksualnym, ale jest faktem. Biologia może jedynie utrudniać realizację właśnie tych społecznych skryptów, które nie odpowiadają potrzebom wszystkich. Pytanie, czy naprawdę każdy z nas musi w te skrypty się wpisywać.

W przedstawionych danych i z analiz wynika, że pewne błędne założenia co do seksualności osób z niepełnosprawnościami mają charakter ponadkulturowy, ponadgeograficzny. Wymienione przeze mnie trzy czynniki: komunikacja, kompensacja niepełnosprawności i warunki fizyczne zdają się mieć znaczący wpływ na możliwość realizowania potrzeb seksualnych osób z niepełnosprawnościami, rozumianych szerzej jako wieloaspektowy element ludzkiego życia. Na występowanie lub nie tych czynników wpływa rodzaj niepełnosprawności. Dla osób, które nie są niepełnosprawne, istotna jest możliwość komunikacji opartej o uwspólnioną wiedzę. W kontekście relacji z osobami z niepełnosprawnością intelektualną istnieje obawa o brak możliwości skutecznej komunikacji.

Niepełnosprawność intelektualna postrzegana jest również jako ta, którą trudno kompensować. Drugim przykładem niepełnosprawności, którą nie zawsze da się kompensować, co może mieć przełożenie na możliwość realizowania potrzeb seksualnych, jest niepełnosprawność o podłożu genetycznym. W przypadku partnerstwa kobiety i mężczyzny, którzy w przyszłości chcieliby posiadać wspólne biologiczne potomstwo, niepełnosprawność o podłożu genetycznym może rodzić obawy o zdrowie dzieci.

Co do warunków fizycznych, badanie pokazało, że, szczególnie w przypadku kobiet z niepełnosprawnościami, fizyczna atrakcyjność ma dla potencjalnych partnerów znaczenie. Pojawia się tutaj jednak pewna sprzeczność. Jednocześnie pozytywnie postrzegana jest atrakcyjność fizyczna u kobiet z niepełnosprawnością i prowadzi do to dysonansu poznawczego, bo niepełnosprawność nie kojarzy się z dbałością o wygląd zewnętrzny. Osoba z niepełnosprawnością częściej „ubierana jest" przez społeczeństwo w wygodny szary dres.

Każdy z powyższych aspektów wiąże się z kwestią, która intuicyjnie może być oczywista, ale warto o niej wspomnieć. W budowaniu społeczeństwa, w którym każda jednostka z niepełnosprawnością będzie mogła funkcjonować w sposób dla siebie zadowalający, istotna jest styczność przestrzenna. Warunkuje ona nie tylko zaistnienie sytuacji potencjalnie sprzyjających 
realizowaniu potrzeb seksualnych, co jest warunkiem niezbędnym, ale również sprzyja niejednostronnemu definiowaniu niepełnosprawności. Osoba z niepełnosprawnością, jawiąca się jako „inny”, „dewiant” (Goffman 2005), często jest figurą obecną w społecznym świecie, mediach, stereotypach, a nie jednostką, którą znamy osobiście. Styczność przestrzenna jest niezbędna również po to, żeby stereotypy mogła zastąpić wiedza wynikająca z doświadczenia.

Seksualność ludzka to kwestia, która dotyczy każdego, była i zapewne będzie poddawana dyskusji jeszcze wielokrotnie. Istotne jest, abyśmy w tej dyskusji nie zapominali o kilku naukowych faktach. Po pierwsze, seksualność ludzka jest płynna, dlatego krzywdzące dla osób z niepełnosprawnościami jest przekonanie, że z powodu odmiennych warunków fizycznych nie są one w stanie realizować swoich potrzeb seksualnych. Po drugie, na te warunki fizyczne nakładają się

\section{Bibliografia}

Bourdieu Pierre (2005) Dystynkcja. Społeczna krytyka władzy sadzenia. Przełożył Piotr Biłos. Warszawa: Wydawnictwo Naukowe Scholar.

Deklaracja praw seksualnych (2003) „Seksuologia Polska”, t. 1, nr 1, s. 1-2.

Foucault Michel (1998) Podmiot i władza. „Lewą Nogą”, nr 9, s. 174-192.

Freud Sigmund (1999) Trzy rozprawy z teorii seksualnej [w:] Freud Sigmund, Życie seksualne. Warszawa: Wydawnictwo KR, s. 37-54.

Fundacja Kulawa Warszawa (2019) Przychodzi baba do lekarza [dostęp 2 lutego 2020 r.]. Dostępny w Internecie: 〈https://www. kulawawarszawa.pl/wp-content/uploads/2019/03/Fundacja_ Kulawa_Warszawa_dost $\%$ C4\%99pno\%C5\%9B\%C4\%87_gabinet\%C3\%B3w_ginekologicznych.pdf».

Gagnon John, Simon William (1973) Sexual conduct. The social sources of human sexuality. Chicago: Aldine. warunki społeczne. Górnolotnym byłoby stwierdzenie, że musimy mieć świadomość, że każdy z nas je tworzy, niemniej uważam, że to prawda. Obraz seksualności osób z niepełnosprawnościami powinien zmienić swój kształt i zaczaćć odzwierciedlać faktyczną wiedzę na ten temat. Wiem, że to zadanie trudne, ale wierzę, że możliwe do zrealizowania.

Badania nad seksualnością osób z niepełnosprawnościami doprowadziły mnie do jeszcze jednej hipotezy, niezwiązanej już bezpośrednio z ludzką seksualnością a mianowicie, że wszystkie obecne w różnych czasach i miejscach modele niepełnosprawności nie odpowiadają na pytanie, czym właściwie niepełnosprawność jest. Odpowiadają raczej na pytanie, jakie konsekwencje niepełnosprawność ze sobą niesie i w jaki sposób możemy je niwelować. Ten wątek jest poboczny w kontekście powyższej analizy, ale w moim przekonaniu istotny i warty pogłębienia w dalszych badaniach.

Glaser Barney G., Strauss Anselm L. (2016) Świadomość umierania. Przełożył Paweł Tomanek. Kraków: Zakład Wydawniczy Nomos.

Goffman Erving (2005) Piętno. Przełożyły Aleksandra Dzierżyńska, Joanna Tokarska-Bakir. Gdańsk: Gdańskie Wydawnictwo Psychologiczne.

Hawkes Gail (2002) A sociology of sex and sexuality. Philadelphia: Open University Press.

Hinc-Wirkus Magdalena (2017) „Upośledzony” seks, czyli o seksualności osób z niepetnosprawnościa w Polsce. "Czasopismo Pedagogiczne", t. 1, s. 22-29.

Hunt Xanthe (2017) Dating persons with physical disabilities: the perceptions of South Africans without disabilities. "Culture, Health and Sexuality", vol. 20, s. 141-155.

Kochanowski Jacek (2013) Socjologia seksualności. Marginesy. Warszawa: Wydawnictwo Naukowe PWN. 
Konecki Krzysztof (2000) Studia z metodologii badań jakościowych. Teoria ugruntowana. Warszawa: Wydawnictwo Naukowe PWN.

Nguyen Thi T. A. (2019) Sexual experiences of people with physical disabilities in Vietnam. „Sexuality and Disability”, vol. 37, s. 25-39.

Niedbalski Jakub, Racław Mariola, Żuchowska-Skiba Dorota (2017) Wstęp. W kierunku nowego paradygmatu niepetnosprawności. „Acta Universitatis Lodziensis”, t. 60, s. 5-12.

Polskie Towarzystwo Stwardnienia Rozsianego (2006) SM $i$ najważniejsze fakty. Warszawa: Polskie Towarzystwo Stwardnienia Rozsianego.

Rubin Gayle (2004) Rozmyślając o seksie: zapiski o sprawie radykalnej teorii polityki seksualności. Przełożyła Joanna Mizielińska. „Lewą nogą", t. 16, s. 164-224.

Rzeźnicka-Krupa Joanna (2019) Społeczne ontologie niepełnosprawności. Ciało. Tożsamość. Performatywność. Kraków: Wydawnictwo Impuls.

Santos Ana C, Santos Ana L. (2018) Yes, we fuck! Challenging the misfit sexual body through disabled women's narratives. „Sexualities", vol. 21, s. 303-318.

Seidman Steven (2012) Społeczne tworzenie seksualności. Przełożył Paweł Tomanek. Warszawa: Wydawnictwo Naukowe PWN.
Shakespeare Tom (2000) Disabled Sexuality: Toward Rights and Recognition. „Sexuality and Disability”, vol. 18, s. 159-166.

Siebers Tobin (2012) A sexual culture for disabled people [w:] McRuer Robert, Mollow Anna, red., Sex and Disability. London: Duke University Press, s. 37-53.

Smith Rainey Sarah (2018) The pleasures of care. "Sexualities", vol. 21, s. 271-286.

Tarasoff Lesley A. (2015) Experiences of Women With Physical Disabilities During the Perinatal Period: A Review of the Literature and Recommendations to Improve Care. „Health Care for Women International”, vol. 36, s. 88-107.

Tepper Mitchell S. (2000) Sexuality and Disability: The Missing Discourse of Pleasure. „Sexuality and Disability”, vol. 18, s. 283-290.

Walentynowicz Halina (2018) Społeczne prognozy Marksa. „Przegląd Filozoficzny - Nowa Seria", nr 4, s. 203-216.

Wendell Susan (1989) Toward a feminist theory of disability. „Hypatia”, vol. 4, no. 2, s. 104-124.

Wiliński Mateusz (2010) Modele niepetnosprawności: indywidualny funkcjonalny - społeczny [w:] Anna Brzezińska, Radosław Kaczan, Karolina Smoczyńska, red., Diagnoza potrzeb i modele pomocy dla osób z ograniczeniami sprawności. Warszawa: Scholar, s. 15-59.

\section{Cytowanie}

Trojanowska Milena (2020) Komu wolno pójść na randkę? O seksualności osób z niepetnosprawnościami. „Przegląd Socjologii Jakościowej”, t. 16, nr 3, s. 56-69 [dostęp dzień, miesiąc, rok]. Dostępny w Internecie: 〈www.przegladsocjologiijakosciowej.org〉. DOI: http://dx.doi.org/10.18778/1733-8069.16.3.04

\section{Who is Allowed to Go on a Date? About the Sexuality of People with Disabilities}

Abstract: Sexuality is an inseparable part of our life and identity. The most of the population was born - and lives as - sexually significant, apart from the group of people who are described as asexual. The laws of biology, however, are not always defined in the same way as socially constructed meanings. Do women with disabilities have the right to go on a date? What barriers do they need to struggle with when they decide to have children? Can they care about their sexual needs? What sexual activities are described by socially acceptable sex scripts? I will try to answer these questions on the basis of literature analysis as well as my own research results. My research was carried out on a group of women living with disabilities (multiple sclerosis) and their partners, as well as with a group of people who have no daily contact with people with disabilities.

Keywords: disability, sexuality, relationships, symbolic interactionism 